\section{Role of iron metabolism genetic determinants in response to chelation therapy in a cohort of $\beta$-thalassemia and sickle cell syndromes Italian patients}

Maria Concetta Renda, Disma Renda, Angela Piazza, Giuseppina Calvaruso, Emanuela Fecarotta, Antonino Giangreco, Aurelio Maggio

UOC Ematologia per le Malattie Rare del Sangue e degli Organi Ematopoietici, AO Ospedali Riuniti Villa Sofia-Cervello, Palermo, Italy

\section{Abstract}

In patients with $\beta$-thalassemia and sickle cell syndromes there is an important secondary iron overload due to regular blood transfusions and increased duodenal iron absorption. As in genetic hemochromatosis, also the secondary iron storage leads to tissue injury that involves all the major organs: liver, heart, kidney, endocrine glands. At present, in patients with $\beta$-thalassemia and sickle cell syndrome, iron chelation therapy is widely used for the treatment of secondary hemochromatosis, to limit the toxic effects of iron overload. In order to maintain the correct homeostasis, several genes are involved in the metabolic pathways of iron, including HFE, FPN (ferroportin) and $T F$ (transferrin). In this study we analyzed the genes HFE, FPN and TF, to assess their possible effects on response to therapy with deferasirox and deferiprone, either as monotherapy or in combination therapy in a cohort of patients with $\beta$-thalassemia and sickle cell syndromes.

\section{Introduction and Rationale}

In patients with $\beta$-thalassemia and sickle cell syndrome, in addition to anemia due to a deficient production of $\beta$-globin chains, there is significant iron storage in the main organs due to periodic blood transfusions, and to an increased absorption of iron in the duodenum approximately three times higher than the normal. As in genetic hemochromatosis, ${ }^{1-3}$ also the secondary iron storage leads to tissue injury that involves all the major organs: liver, heart, kidney, endocrine glands.

Iron storage, especially when secondary to a non-intensive blood transfusion regimen, may be worsened by mutations in genes responsi- ble for primary hemochromatosis, and by an inappropriate mechanism of hepcidin regulation.-6

The presence of one or both of such conditions may give rise, in these patients, to variations in the severity of secondary hemochromatosis and response to chelation therapy.

In order to maintain the correct homeostasis, several genes are involved in the metabolic pathways of iron, including HFE (high iron $F e$ ), $F P N$ (ferroportin) and $T F$ (transferrin).

The HFE gene is responsible for hemochromatosis type I and it is involved in the regulation of iron-transferrin binding. Mutations in HFE cause failure of hepicdin synthesis and intrahepatic iron accumulation. ${ }^{7}$

The FPN gene encodes for the protein ferroportin (FP). FP is the main cellular iron exporter, it is regulated by hepcidin and promotes the iron release from enterocytes and macrophages towards the bloodstream Mutations within FPN lead to an alteration of FP the functions and are responsible for autosomal dominant hereditary hemochromatosis Type IV, also called ferroportin disease, characterized by iron stores in the reticulum endothelium..$^{8,9}$

The most common FPN mutations are loss of function, they reduce FP expression causing iron retention and restrict iron available for erythropoiesis..$^{8,10}$

Moreover, there are very rare FPN gain-offunction mutations making FP resistant to hepcidin regulation. These FP variants give rise to a hepcidin-resistant hemochromatosis, where FP is not internalized and remains on the macrophages surface, increasing the share of available iron. ${ }^{11}$

TF gene encodes for transferrin, a glycoprotein whose function is the transport of iron from the intestine, reticuloendothelial system, and liver parenchymal cells to all proliferating cells in the body. HFE and TF compete for binding the TF receptor. ${ }^{7,9}$

Mutations in TF are responsible for familial hypotransferrinemia, a rare recessive disease characterized by an extremely low transferrin level $[0.1 \mathrm{~g} / \mathrm{L}(10 \mathrm{mg} / \mathrm{dL})]$ and severe hypochromic anemia with iron overload in the liver and other parenchymal organs. Mutations causing the total absence of TF are incompatible with life. ${ }^{7-9}$

At present, in patients with $\beta$-thalassemia and sickle cell syndrome, iron chelation therapy is widely used for the treatment of secondary hemochromatosis to limit the toxic effects of iron overload.

So far, different chelators are used in protocols of iron chelation in polytransfused patients. Deferasirox (DFX) and deferiprone (DFP) are two of the most widely used chelators, having different ways of iron binding. ${ }^{12}$

DFX is a tridentate orally administered iron chelator. DFX is rapidly absorbed, and the main
Correspondence: Maria Concetta Renda, UOC Ematologia per le Malattie Rare del Sangue e degli Organi Ematopoietici, A0 Ospedali Riuniti Villa Sofia-Cervello, via Trabucco 180, 90146 Palermo, Italy.

Tel.: +39.091.6802768 - Fax: +39.091 .6880828 .

E-mail: mc_renda@libero.it

Key words: chelation therapy, iron overload, $\beta$ thalassemia, sickle cell syndromes.

Contributions: GC, MCR, DR, AM, planned the study; MC Renda wrote the manuscript; AM, revised the manuscript; $\mathrm{EF}$, AP performed the genetic analysis; GC, AG, DR, AM established clinical diagnosis and pharmacological treatment.

Conflict of interests: the authors declare no potential conflict of interests.

Received for publication: 18 February 2014.

Revision received: 23 June 2014.

Accepted for publication: 2 July 2014.

This work is licensed under a Creative Commons Attribution 3.0 License (by-nc 3.0).

CCopyright M.C. Renda et al., 2014

Licensee PAGEPress, Italy

Thalassemia Reports 2014; 4:2729

doi:10.4081/thal.2014.2729

route of excretion is in the feces. ${ }^{12}$

DFP chemically behaves as an antioxidant; it is a molecule able to bind the iron in a molar ratio of 3:1, absorption is rapid and the drug is mainly excreted in the urine. ${ }^{12}$

In this study we analyzed the genes $H F E$, $F P N$ and $T F$, to assess the possible effects on response to therapy with DFX and DFP, either as monotherapy or in combination therapy in a cohort of patients with $\beta$-thalassemia and sickle syndromes. ${ }^{13}$ To this aim different levels of serum ferritin have been analyzed and compared in patients undergone to the same therapeutic chelating protocol but with different genotypes.

\section{Materials and Methods}

Thirty patients, aged between 16 and 65 years, were studied: twenty-nine were affected by $\beta$-thalassemia and 1 was affected by sickle cell syndrome.

$\beta$-thalassemia patients were regularly transfused, while the patient with sickle cell syndrome was not transfused. The demographic and clinical characteristics of all patients are summarized in Table 1.

Patients were divided into 3 treatment groups: i) DFX-monotherapy; ii) DFP- 
monotherapy; iii) sequential therapy- DFX 3 $\mathrm{d} / \mathrm{w}$ - DFP $4 \mathrm{~d} / \mathrm{w}$ (Table 1).

Having obtained the informed consent for molecular studies according to institutional guidelines, genomic DNA was extracted from peripheral blood mononuclear cells by means of sodium dodecyl sulfate-phenol/chloroform extraction technique.

$H F E, F P N$ and $T F$ genes encoding and flanking regions were investigated by direct genomic sequencing and restriction endonucleases. Specific polymerase chain reactions (PCR) and direct sequencing primers for HFE, FPN and $T F$ genes were designed in our laboratory on the basis of sequence databases (GENATLAS: http//www.ncbi.nlm.nih.gov).

Specific PCRs were carried out on genomic DNAs in a thermal cycler using $10 \mathrm{mM}$ each primers and $2.5 \mathrm{U}$ Taq polymerase in a final volume of $50 \mu \mathrm{L}$. Direct sequencing was performed using a Genome Lab DTCS Quick Start Kit for Dye Terminator Cycle Sequencing (Beckman Coulter, Inc., Brea, CA, USA), in the Genetic Analysis System CEQ8800 (Beckman Coulter) (Figure 1) .

The S208S polymorphism in the $T F$ gene was investigated by the restriction endonuclease Dde I (Figure 2).

\section{Results}

Results are summarized in Table 2. The patients were divided into three groups depending on chelation therapy they underwent. For each group of patients, HFE, FPN and TF genotypes were related to specific chelation therapy, the number of transfusions per year and the mean values of ferritin.

\section{HFE gene}

Of the 30 patients analyzed, 10 (33.3\%) were heterozygous for the H63D mutation, 1 (3.3\%) was heterozygous for the C282Y mutation; none of the patients was homozygous or compound heterozygous (Table 2).

The allele frequencies of the $\mathrm{C} 282 \mathrm{Y}$ and H63D variants were $16.7 \%$ and $1.7 \%$, respectively (Sicilian healthy people allele frequency $20.5 \%$ and $0.7 \%$ ).

\section{FPN gene}

None of the analyzed patients had mutations in the FPN 3,5,6,7,8 exons. Fourteen out of thirty (46.6\%) were homozygous for the notdisease linked polymorphism Val221Val T>C; $12 / 30$ (40\%) were heterozygous and $4 / 30$ (13.4\%) were negative for this polymorphism (Table 2).

\section{TF gene}

For the $T F$ gene were analyzed the polymorphism S208S, and the variant G277S, the latter in linkage disequilibrium with the polymorphism L247L. These variants are all associated with a reduction of total iron binding capacity.
Seventeen out of thirty patients (56.7\%) were negative for all the analyzed variants; $8 / 30$ (26.7\%) patients were heterozygous for the polymorphism S208S; $1 / 30 \quad(3.3 \%)$ was homozygous S208S; 1/30 (3.3\%) was heterozygous for the polymorphism L247L; 3/30 (10\%)

Table 1. Demographic and clinical features of the 30 studied patients.

\begin{tabular}{lc} 
& No. \\
Gender & \\
Males & 9 \\
Females & 21 \\
Mean age (years) & 34.23 (SD \pm 11.92$)$ \\
\hline $\begin{array}{l}\text { Hemoglobinopathies } \\
\quad 3 \text {-thalassemia }\end{array}$ & 29 \\
Sickle cell disease & 1 \\
Transfusional therapy & \\
Yes & 29 \\
No & 1 (patient with SCD) \\
\hline Iron chelation therapy & \\
Yes & 30 \\
No & 0 \\
DFX monotherapy & 13 \\
\hline DFP monotherapy & 11 \\
Sequential therapy DFX 3 & 6 \\
d/w DFP 4 d/w & \\
\hline SD, standard deviation; SCD, sickle cell disease; DFX, deferasirox;
\end{tabular}

SD, standard deviation; SCD, sickle cell disease; DFX, deferasirox; DFP, deferiprone.
$\mathbf{A}$

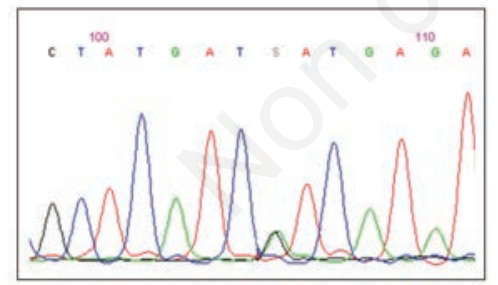

B

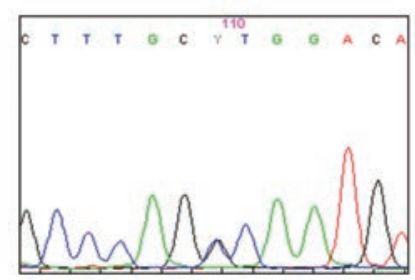

C

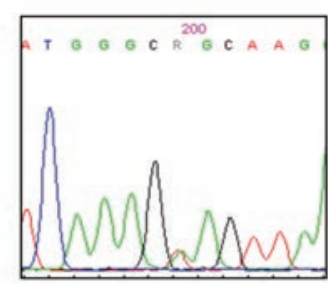

12345567891011121314

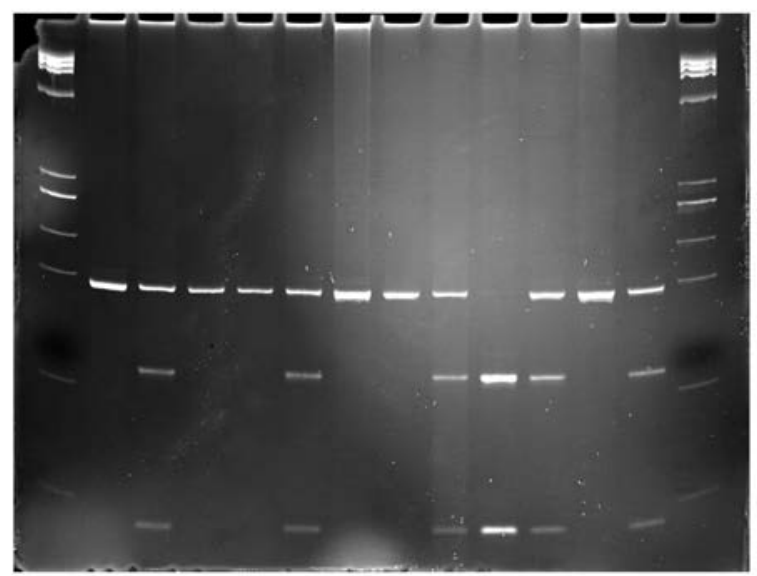

Figure 1. Direct gene sequencing. A) exon 2 of $H F E$ gene: heterozygous H63D; B) exon 7 of TF gene: heterozygous L247L; C) exon 7 of $T F$ gene: heterozygous G277S.
Figure 2. TF S208S polymorphism Dde I restriction fragments. Lanes 1 and 14: $\varphi$ X174 Hae III; lane 2 negative control; lanes 4, 5, 7, 8 and 12: negative samples; lanes $3,6,9,11$ and 13: heterozygous samples; lane 10: homozygous sample. 
were heterozygous for both the polymorphism L247L and the mutation G277S (Table 2).

\section{Discussion and Conclusions}

In Sicilian population one of the major causes of iron overload is the state of homozygosity for $\beta$-thalassemia and sickle cell syndrome. In these patients, iron storage is due to blood regular transfusions, and to the increase of iron absorption in the duodenum secondary to erythroid hyperplasia.

Iron-chelating therapy allows controlling iron storage.
In these patients the presence of mutations responsible of hereditary hemochromatosis, could influence the severity of secondary hemochromatosis and the response to chelation therapy.

All patients but one, of the present study were regularly transfused and all underwent chelation therapy: DFX-monotherapy, DFPmonotherapy or 3-sequential therapy DFX 3 $\mathrm{d} / \mathrm{w}$ - DFP $4 \mathrm{~d} / \mathrm{w}$.

Because none of the patients showed mutations within the gene FPN, for this cohort of patients is not possible to determine the influence of the FPN gene on the response to iron chelation therapy.

Data obtained by molecular analysis of the
$H F E$ and $T F$ genes, suggest that in $\beta$-thalassemia patients regularly transfused, the heterozygous state for one of three major HFE mutations (C282Y, H63D, S65C) and/or the presence of $T F$ gene variants, does not affect the serum ferritin levels.

In fact, the serum ferritin levels found in these patients, do not differ with regard to different HFE and TF genotypes, but to the number of transfusions per year and to the chelation therapy they undergo. This indicating the transfusional protocol and the chelation regimen as the main indicators of the severity and variability of iron overload.

Table 2. Patients' genotypes and phenotypes related to transfusional and chelating therapy.

\begin{tabular}{|c|c|c|c|c|c|c|c|c|c|c|c|}
\hline Group 1 DFX & Gender & Age & $\begin{array}{l}\text { Phen. } \\
\beta \text {-thal }\end{array}$ & $\beta$-globin & HFE & enotyp & S208S & $\begin{array}{c}\mathrm{TF} \\
L 247 L\end{array}$ & $G 277 S$ & TX/Y & $\begin{array}{l}\text { Ferritin } \\
\mathrm{ng} / \mathrm{mL}\end{array}$ \\
\hline 1 & $\mathrm{~F}$ & 23 & $\mathrm{TM}$ & Cd39//IVS1,nt110 & $\mathrm{H} 63 \mathrm{D} / \mathrm{N}$ & $\mathrm{N} / \mathrm{N}$ & Het & $\mathrm{N}$ & $\mathrm{N}$ & 16 & 587.1 \\
\hline 2 & $\mathrm{~F}$ & 51 & TI & Cd39/IVS1,nt6 & $\mathrm{H} 63 \mathrm{D} / \mathrm{N}$ & $\mathrm{N} / \mathrm{N}$ & $\mathrm{N}$ & $\mathrm{N}$ & $\mathrm{N}$ & 12 & 5.680 \\
\hline 3 & M & 36 & $\mathrm{TM}$ & IVS1 nt110/IVS1,nt1 & $\mathrm{N} / \mathrm{N}$ & $\mathrm{N} / \mathrm{N}$ & Het & $\mathrm{N}$ & $\mathrm{N}$ & 26 & 2.079 \\
\hline 4 & M & 31 & $\mathrm{TI}$ & IVS1,nt 6/ IVS1,nt 110 & $\mathrm{H} 63 \mathrm{D} / \mathrm{N}$ & $\mathrm{N} / \mathrm{N}$ & $\mathrm{N}$ & $\mathrm{N}$ & $\mathrm{N}$ & 20 & 799.8 \\
\hline 5 & $\mathrm{~F}$ & 43 & $\mathrm{TM}$ & $\mathrm{Cd} 39 / \mathrm{Cd} 39$ & $\mathrm{~N} / \mathrm{N}$ & $\mathrm{N} / \mathrm{N}$ & Het & $\mathrm{N}$ & $\mathrm{N}$ & 18 & 471.9 \\
\hline 6 & M & 35 & TM & IVS1,nt110/IVS1, nt1 & $\mathrm{N} / \mathrm{N}$ & $\mathrm{N} / \mathrm{N}$ & $\mathrm{N}$ & $\mathrm{N}$ & $\mathrm{N}$ & 16 & 1.838 \\
\hline 7 & $\mathrm{~F}$ & 36 & TM & IVS1,nt110/IVS1,nt110 & $\mathrm{N} / \mathrm{N}$ & $\mathrm{N} / \mathrm{N}$ & Het & $\mathrm{N}$ & $\mathrm{N}$ & 38 & 2.243 \\
\hline 8 & $\mathrm{~F}$ & 39 & $\mathrm{TM}$ & IVS1,nt1/IVS1,nt5 & $\mathrm{H} 63 \mathrm{D} / \mathrm{N}$ & $\mathrm{N} / \mathrm{N}$ & $\mathrm{N}$ & $\mathrm{N}$ & $\mathrm{N}$ & 17 & 1476 \\
\hline 9 & $\mathrm{~F}$ & 20 & TM & Cd39/IVS1,nt110 & $\mathrm{H} 63 \mathrm{D} / \mathrm{N}$ & $\mathrm{N} / \mathrm{N}$ & $\mathrm{N}$ & $\mathrm{N}$ & $\mathrm{N}$ & 28 & 1871 \\
\hline 10 & $\mathrm{~F}$ & 37 & $\mathrm{TM}$ & $\mathrm{Cd} 39 / \mathrm{Cd} 39$ & $\mathrm{H} 63 \mathrm{D} / \mathrm{N}$ & $\mathrm{N} / \mathrm{N}$ & $\mathrm{N}$ & $\mathrm{N}$ & $\mathrm{N}$ & 27 & 1891 \\
\hline 11 & $\mathrm{~F}$ & 50 & TM & IVS1,nt6/ fr.76 & $\mathrm{N} / \mathrm{N}$ & $\mathrm{N} / \mathrm{N}$ & $\mathrm{N}$ & Het & Het & 19 & 824.6 \\
\hline 12 & $\mathrm{~F}$ & 56 & $\mathrm{TI}$ & IVS1,nt10/IVS1,nt6 & $\mathrm{N} / \mathrm{N}$ & $\mathrm{N} / \mathrm{N}$ & $\mathrm{N}$ & $\mathrm{N}$ & $\mathrm{N}$ & 15 & 417.2 \\
\hline 13 & M & 30 & TM & IVS1,nt1/ IVS1,nt6 & $\mathrm{H} 63 \mathrm{D} / \mathrm{N}$ & $\mathrm{N} / \mathrm{N}$ & $\mathrm{N}$ & Het & Het & 12 & 1.806 \\
\hline \multicolumn{12}{|l|}{ Group 2 DFP } \\
\hline 1 & $\mathrm{~F}$ & 65 & $\mathrm{TI}$ & IVS2, nt1/NI & $\mathrm{H} 63 \mathrm{D} / \mathrm{N}$ & $\mathrm{N} / \mathrm{N}$ & $\mathrm{N}$ & $\mathrm{N}$ & $\mathrm{N}$ & 13 & 2.036 \\
\hline 2 & $\mathrm{~F}$ & 25 & TM & INS2, nt1/ IVS1, nt110 & $\mathrm{H} 63 \mathrm{D} / \mathrm{N}$ & $\mathrm{N} / \mathrm{N}$ & $\mathrm{N}$ & $\mathrm{N}$ & $\mathrm{N}$ & 20 & 928 \\
\hline 3 & $\mathrm{~F}$ & 31 & $\mathrm{TM}$ & IVS1,nt110/IVS1,nt110 & $\mathrm{C} 282 \mathrm{Y} / \mathrm{N}$ & $\mathrm{N} / \mathrm{N}$ & Homoz & $\mathrm{N}$ & $\mathrm{N}$ & 24 & 1.415 \\
\hline 4 & M & 34 & TM & $\mathrm{Cd} 39 / \mathrm{Cd} 39$ & $\mathrm{~N} / \mathrm{N}$ & $\mathrm{N} / \mathrm{N}$ & $\mathrm{N}$ & $\mathrm{N}$ & $\mathrm{N}$ & 13 & 1690 \\
\hline 5 & $\mathrm{~F}$ & 53 & $\mathrm{TM}$ & Cd39/IVS1,nt110 & $\mathrm{N} / \mathrm{N}$ & $\mathrm{N} / \mathrm{N}$ & Het & $\mathrm{N}$ & $\mathrm{N}$ & 19 & 837.5 \\
\hline 6 & $\mathrm{~F}$ & 33 & TM & IVS1,nt110/IVS1,nt110 & $\mathrm{N} / \mathrm{N}$ & $\mathrm{N} / \mathrm{N}$ & $\mathrm{N}$ & $\mathrm{N}$ & $\mathrm{N}$ & 21 & 1.532 \\
\hline 7 & $\mathrm{~F}$ & 23 & TM & Cd39/IVS1,nt110 & $\mathrm{H} 63 \mathrm{D} / \mathrm{N}$ & $\mathrm{N} / \mathrm{N}$ & $\mathrm{N}$ & $\mathrm{N}$ & $\mathrm{N}$ & 27 & 1.652 \\
\hline 8 & M & 16 & TM & Cd39/IVS1,nt110 & $\mathrm{N} / \mathrm{N}$ & $\mathrm{N} / \mathrm{N}$ & Het & Het & $\mathrm{N}$ & 21 & 1.611 \\
\hline 9 & $\mathrm{~F}$ & 20 & TI & IVS1,nt6/IVS1,nt110 & $\mathrm{N} / \mathrm{N}$ & $\mathrm{N} / \mathrm{N}$ & $\mathrm{N}$ & $\mathrm{N}$ & $\mathrm{N}$ & 19 & 1.888 \\
\hline 10 & M & 32 & TI & IVS1,nt6 /IVS1,nt 6 & $\mathrm{~N} / \mathrm{N}$ & $\mathrm{N} / \mathrm{N}$ & Het & $\mathrm{N}$ & $\mathrm{N}$ & 14 & 676.2 \\
\hline 11 & $\mathrm{~F}$ & 27 & SCD & $\beta S / \beta S$ & $\mathrm{~N} / \mathrm{N}$ & $\mathrm{N} / \mathrm{N}$ & $\mathrm{N}$ & $\mathrm{N}$ & $\mathrm{N}$ & 0 & 896.6 \\
\hline \multicolumn{12}{|c|}{ Group 3 DFX 3 d/w DFP 4 d/w } \\
\hline 1 & $\mathrm{~F}$ & 32 & $\mathrm{TM}$ & $\mathrm{Cd} 39 / \mathrm{Cd} 39$ & $\mathrm{~N} / \mathrm{N}$ & $\mathrm{N} / \mathrm{N}$ & $\mathrm{N}$ & $\mathrm{N}$ & $\mathrm{N}$ & 22 & 2.915 \\
\hline 2 & M & 21 & TM & IVS1,6/Cd39 & $\mathrm{N} / \mathrm{N}$ & $\mathrm{N} / \mathrm{N}$ & $\mathrm{N}$ & Het & Het & 13 & 1.547 \\
\hline 3 & M & 31 & $\mathrm{TM}$ & Cd39/IVS1nt110 & $\mathrm{N} / \mathrm{N}$ & $\mathrm{N} / \mathrm{N}$ & $\mathrm{N}$ & $\mathrm{N}$ & $\mathrm{N}$ & 23 & 1.696 \\
\hline 4 & $\mathrm{~F}$ & 43 & TM & Cd39/-87 & $\mathrm{N} / \mathrm{N}$ & $\mathrm{N} / \mathrm{N}$ & $\mathrm{N}$ & $\mathrm{N}$ & $\mathrm{N}$ & 17 & 1027.3 \\
\hline 5 & $\mathrm{~F}$ & 36 & $\mathrm{TM}$ & Cd39/IVS1,nt6 & $\mathrm{N} / \mathrm{N}$ & $\mathrm{N} / \mathrm{N}$ & Het & $\mathrm{N}$ & $\mathrm{N}$ & 13 & 1200 \\
\hline 6 & $\mathrm{~F}$ & 18 & TM & Cd39/IVS1,nt6 & $\mathrm{N} / \mathrm{N}$ & $\mathrm{N} / \mathrm{N}$ & Het & $\mathrm{N}$ & $\mathrm{N}$ & 16 & 2.877 \\
\hline
\end{tabular}

Phen., phenotype; DFX, deferasirox; TM, thalassemia major; N, negative; Het, heterozygous; TI, thalassemia intermedia; DFP, deferiprone; Homoz, homozygous; SCD, sickle cell disease. 


\section{References}

1. Fiorelli G, Fargion S, Piperno A, et al. Iron metabolism in thalassemia intermediate. Haematologica 1990;75:89-95.

2. Allen KJ, Gurrin LC, Constantine CC, et al. Iron-overload-related disease in HFE hereditary hemochromatosis. N Engl J Med 2008;358:221-30.

3. Pietrangelo A. Hereditary hemochromatosis - a new look at an old disease. $\mathrm{N}$ Engl $\mathrm{J}$ Med 2004;350:2383-97.

4. Cianetti L, Gabbianelli M, Sposi NM. Ferroportin and erythroid cells: an update. Adv Hematol 2010;2010. pii: 404173.

5. Pietrangelo A. Hereditary hemochromatosis.
Biochim Biophys Acta 2006;1763:700-10.

6. Politou M, Kalotychou V, Pissia M, et al. The impact of the mutations of the HFE gene and of the SLC11A3 gene on iron overload in Greek thalassemia intermedia and $\mathrm{bS} / \mathrm{bthal}$ anemia patients. Haematologica 2004;89:490-2.

7. Pietrangelo A. Hemochromatosis: an endocrine liver disease. Hepatology 2007; 46:1291-301.

8. Ganz T, Nemeth E. The hepcidin-ferroportin system as a therapeutic target in anemias and iron overload disorders. Hematology Am Soc Hematol Educ Program 2011;2011:538-42.

9. Pietrangelo A. Molecular insights into the pathogenesis of hereditary haemochro- matosis. Gut 2006;55:564-8.

10. Mayr R, Janecke AR, Schranz M, et al. Ferroportin disease: a systematic metaanalysis of clinical and molecular findings. J Hepatol 2010;53:941-9.

11. Camaschella C Silvestri L. Molecular mechanisms regulating hepcidin revealed by hepcidin disorders. Sci World J 2011; 11:1357-66.

12. Maggio A. Light and shadows in the iron chelation treatment of haematological diseases. Br J Haematol 2007;138:407-21.

13. Maggio A, Vitrano A, Capra M, et al. Longterm sequential deferiprone-deferoxamine versus deferiprone alone for thalassaemia major patients: a randomized clinical trial. Br J Haematol 2009;145:245-54. 